\title{
Analysis on the Teaching Reform of Real Estate Appraisal Course Under the "Internet and Education" Mode
}

\author{
Ling Chen \\ Fuzhou University of International Studies and Trade \\ Fuzhou, China 350001
}

\begin{abstract}
At present, "Internet plus" has penetrated into all walks of life in the society, promoting the informationization of industry operations and the updating of the industry technology, and improving industry efficiency. At the same time, "Internet plus" also has a profound impact on educational resources such as educational resources, teaching models and learning models. Based on the background of "Internet and Education", with curriculum design reform as the core, this paper analyzes the existing problems in real estate valuation teaching, and puts forward a teaching model of real estate appraisal, which is mainly based on classroom practical skills training and supplemented by online theoretical teaching.
\end{abstract}

Keywords-Internet plus; education; real estate appraisal; online courses; practice

\section{INTRODUCTION}

With the continuous development of Internet information technology, the concept of informatization has penetrated into all walks of life and achieved remarkable results. In 2017, the main points of the General Office of the Ministry of Education on education informatization pointed out: "Accelerate the process of education informationization, improve the education resource cloud service system, promote the development of innovative teaching modes combining online and offline, and deepen the teaching reform [1]."

In the asset assessment practice, real estate valuation is one of the largest special assessments of business volume, and there is a big gap in the demand for social talents. Therefore, the cultivation of real estate appraisal applied talents is of great significance to make up for this gap. Real Estate Valuation is a core course with strong practicality for the major of asset appraisal. Its practicality needs to be based on a large number of theoretical foundations, but the limited course hours make it impossible for teachers to take into account the training of theory and practice [2].The "Internet + Education" teaching model interchanges the classroom teaching activities that were originally taught by teachers and the off-class learning activities that are mainly done by students, in a new online classroom form. Construct an innovative teaching model of real estate valuation based on online student initiative learning and offline teacher guidance practice.

\section{ANALYSIS ON THE ADVANTAGES OF "INTERNET PLUS" TEACHING}

\section{A. Optimizing the Teaching Mode}

The traditional teaching model can be summarized as "teacher teaching, students acquiring". The acquisition of student knowledge mainly comes from teaching materials and teachers 'teaching in the classroom. Therefore, teachers need to spend more time in the classroom to explain basic theoretical knowledge to students. The explanation of the core method and its application is often reduced due to the limitation of class hours, which affects the teaching effect. With the rapid spread of the Internet, the channels for students to acquire knowledge have become diversified. Students can complete the theoretical knowledge reserve of the curriculum through self-learning on the Internet, thus emancipating the constraints of class hours. Teachers can no longer spend a lot of time explaining the basic theoretical knowledge in detail, but discuss the knowledge points through various teaching methods such as communication and case analysis, increase the interaction of teaching and stimulate students' enthusiasm for learning.[3]

\section{B. Optimizing Learning Methods}

Under the traditional teaching mode, learners need to study at the prescribed time and place according to the curriculum arrangement. The object of education is usually the students in school. Therefore, under the traditional teaching mode, the age, identity, time and space of learners are greatly limited. With the help of "Internet +", the reconfiguration and integration of educational resources will enable learners to break through the time and space of learning. No matter whether they are in school or not, as long as they have learning needs, they can log in to the learning platform through mobile terminals anytime and anywhere, and acquire the required learning resources according to their own learning intention, complete online learning. The learning mode has also changed from passive to active. Learners can arrange the learning process independently through Internet technology, and the learning content and time have also changed from centralized to fragmented. Under the traditional teaching model, teaching needs to be performed according to the schedule of teaching. Usually, the class is divided into two classes for a total of 90 minutes. The learners must learn the fixed knowledge at a 
fixed time and a fixed place. Online learning through the Internet can be based on the specific situation, reasonable allocation of learning time, choice of learning content, so Internet education as a supplementary teaching means to consolidate and supplement classroom learning[4].

\section{Open Learning Resources}

Learning resources are from closed to open. Under the traditional model, learning resources are mainly concentrated in a relatively closed space such as a school. They are limited to classrooms and libraries. Whether textbooks or library books and other physical resources are relatively limited, which are unable to meet all learning needs of students. The Internet has strong storage and interactivity, and it can absorb huge amounts of knowledge and information in a short period of time, and constitute a huge information base. As the Internet terminals continuously upload and release new information, this information base is also constantly expanding and updated, the knowledge and information are presented in a digital presentation in various online resource repositories and online learning platforms. The learner can $\log$ in to the online platform through the Internet terminal to obtain the required learning resources[4].

\section{TEACHING StATUS OF REAL EstATE APPRAISAL}

Real Estate Valuation is a core course of assets appraisal and real estate management, and its business volume also occupies the first place in the appraisal industry. Therefore, the social demand for applied talents in real estate appraisal is still in short supply. For applied undergraduate colleges, in other words, the teaching of real estate valuation should pay more attention to the cultivation of practical ability. However, due to the influence of the teaching environment such as class time restrictions, teaching resources and practical conditions, the current teaching mode of real estate appraisal is mainly based on the teaching of classroom theory and method, and the centralized teaching mode supplemented by case guidance. Students also focuses on passive learning, which to a large extent limits the development of practical skills in evaluation[5].

\section{A. Lack of Teaching Resources}

Real Estate Valuation is a comprehensive discipline that involves multidisciplinary fields such as law, economy, construction engineering, planning, and environment. So there are higher requirements for the professional qualities of the teaching teachers. Teachers are required to have sufficient knowledge reserves and rich evaluation practice experience. However, as far as the current teacher conditions are concerned, most of the professional teachers have a narrow knowledge base. Therefore, in the course of real estate valuation teaching, it is difficult to expand the knowledge points[6]. For students, to learn this course well, they also need the knowledge reserve of relevant laws, engineering, environment and so on, and requires students to comprehensively sort out their knowledge structure system, which requires relatively high comprehensive application ability of students, but as far as the whole professional training program is concerned, it is impossible to achieve allround development, which requires students to actively expand the relevant knowledge, and this also increases the difficulty of learning.

\section{B. Class Schedule Is Restricted}

According to statistics, in the course setting of the asset assessment major of colleges and universities in China, due to the need to take into account the time requirements of other special assessments, the course time of Real Estate Valuation ranges from 32 hours to 48 hours (including 16 hours of class practice). As far as the textbook of Real Estate Valuation is concerned, its structure and content are generally consistent regardless of the edition. Taking the textbook edited by Tian Jiefang as an example, the book has a total of 12 chapters, and the 1-5 chapter is the basic knowledge part, covering the concept of real estate valuation, price and value theory, principles, factors and so on, mainly in classroom teaching; Chapters 5-10 are valuation methods, including cost method, market method, income method, hypothesis development method, long-term trend method and so on, which are the core part of the curriculum, and pay more attention to students' mastery and application of methods, therefore, the content of this part is usually based on case teaching; and Chapter 11-12 for various types of mortgage assets valuation and valuation reports and procedures. If the teaching content is required to cover the entire teaching material, then after deducting classroom exercises and discussions, each chapter can only be allocated two class hours, and in terms of valuation methods, two class hours are far from meeting the teaching needs. It is also impossible to take time out to arrange for students to evaluate practical training, which greatly affects the overall teaching effect.[7]。

\section{Single Teaching Method}

Under the traditional teaching mode, teachers need to arrange the teaching progress and content according to the limited class hours, so the teaching methods of teachers are also greatly restrained. And for students, the theoretical basis is the key to learning a course well. Therefore, most teachers are concerned about the mastery of the theoretical basis of students. The teaching method also tends to be based on the teaching of basic knowledge and supplemented by case analysis. In recent years, in order to promote the cultivation of applied talents, the teaching of Real Estate Appraisal Course has been reformed. The direction of reform is inclined to case teaching and project teaching. But, it is often overlooked that case teaching should be based on the solid theoretical foundation of students. However, due to the limitations of the curriculum in terms of time and space, theoretical teaching occupies the main unit of classroom teaching, which limits the teaching of case teaching and project teaching, so that it cannot achieve the expected results.[6]

\section{Lack of Practical Teaching Conditions}

At present, the demand for social talents has gradually shifted from paying attention to academic qualifications to professional skills. Therefore, for the Real Estate Valuation, which is a highly professional and practical course, the training of students' applied ability is particularly important. The cultivation of application ability is inseparable from the practice teaching. On the basis of mastering the basic theoretical knowledge and valuation methods, students need to 
participate in the valuation practice to form their own theoretical system, and apply the valuation method learned to practice, so as to grasp the entire evaluation process, help students to put the rational knowledge learned in the previous period into practice. However, many colleges and universities have insufficient understanding of practical teaching, the construction of professional training simulation laboratory is lagging behind, and there are few teaching cases. Some universities even ignore the class arrangement of real estate valuation practice teaching in the curriculum of talent training programs[8].

\section{E. Assessment Method Focuses on the Score}

At present, the assessment methods of real estate appraisal course in most universities in China are mainly based on the traditional examination papers. The results are mainly composed of the examination papers grades and the ordinary grades, which are usually composed of attendance, classroom performance and homework. The final examination results account for a large proportion, usually $60 \%-70 \%$, and the final examination content tends to master the knowledge of basic theory and apply the evaluation formula. It is impossible to make an accurate evaluation for ability of students to use the evaluation method and the quality of the evaluation process. Therefore, it is not enough to reflect the students' mastery of the course only through the traditional examination.

IV. THOUghtS ON THE REFORM OF TEACHING MODE OF REAL ESTATE APPRAISAL COURSE UNDER THE BACKGROUND OF "INTERNET PLUS"

\section{A. Establishing Online Real Estate Appraisal Course System Group Oriented by "Course Certificate Integration"}

The knowledge system of real estate appraisers covers the Basic System and Policy of Real Estate, Real Estate Development and Management, Real Estate Valuation Theory and Methods, and Real Estate Valuation Case and Analysis. The content structure of Real Estate Appraisal is basically the same as Real Estate Appraisal Theory and Method. As the forerunner of theory and method, Real Estate Basic System and Policy and Real Estate Development and Management are the indispensable knowledge reserves for students to study Real Estate Appraisal. Real Estate Valuation Cases and Analysis pays more attention to the application of real estate valuation theory and methods. These four courses constitute a complete real estate appraisal course system. As one of the many special evaluation courses for asset appraisal, it does not have the weight advantage and therefore cannot take into account the establishment of its related courses. The construction of the online course group can solve such contradictions well. Students can improve the knowledge reserve of Real Estate Appraisal through the study of real estate valuation online course group, form their own knowledge structure system, and incorporate online learning into the final examination.

\section{B. Relying on "Internet +", Breaking the Time and Space Restrictions of Teaching}

In order to get rid of the time and space constraints of the course teaching, the school needs to help the teacher to complete the recording and editing of the online course and upload them to the online teaching resource platform on campus. At the same time, online course recording has also put forward higher requirements for teaching teachers. Teachers should adopt rich teaching methods so that teaching videos do not fall into a boring situation. After the end of each chapter, the corresponding summary and practice should also be accompanied to supervise students 'online course learning and knowledge point mastery.

\section{Taking Traditional Classroom Teaching as a Platform to Give Full Play to the Advantages of the New "Online + Offline" Teaching Model}

Through the online course study and practice, students can master the relevant theoretical knowledge of real estate valuation, including basic concepts, valuation principles, price influencing factors and so on. In the classroom, students can discuss problems with teachers, and teachers no longer need to start with boring knowledge points such as basic theory. In class, teachers can explain the core methods of real estate appraisal in detail, give full play to the advantages of case teaching and project teaching, and combine the explained valuation methods to enable students to understand the use of evaluation methods more intuitively and accurately through teacher case demonstrations. Through project guidance, students can apply methods to project practice, so that teachers' teaching and students' learning can be practical[7].

\section{Project Oriented Classroom Teaching Mode of Real Estate Appraisal Based on Work Engineering}

The training of application-oriented talents is the primary task of application-oriented undergraduate colleges, but the traditional teaching mode emphasizes on the teaching of theoretical knowledge. The training of application-oriented talents pays more attention to the application of knowledge, the improvement of practical ability and the shaping of comprehensive professional quality. Therefore, it is necessary to reform the traditional teaching model, introduce the practical working situation, and design the course module according to the practical process.

The course design of real estate appraisal can be divided into five modules according to the appraisal procedure of real estate project, which are entrusted acceptance, collection of appraisal data, site investigation, appraisal calculation, writing appraisal report and so on. The teaching design can also be further refined according to the difficulty and complexity of the specific work flow[8]. ("Table I") 
TABle I. Course Module Design of Real Estate ApPraisal

\begin{tabular}{|l|l|}
\hline $\begin{array}{l}\text { Module 1: Acceptance the Entrusted of } \\
\text { Appraisal Project }\end{array}$ & $\begin{array}{l}\text { 1.Define the basic items of Appraisal } \\
\text { 2.Sign the appraisal contract }\end{array}$ \\
\hline Module two: Collection of Appraisal Data & $\begin{array}{l}\text { Collect various materials that have an impact on real estate prices, including laws and } \\
\text { regulations, social economy, urban planning, market transactions, construction costs, } \\
\text { infrastructure, environmental quality, traffic conditions, and living facilities. }\end{array}$ \\
\hline Module 3: Site Investigation & $\begin{array}{l}\text { Physical, rights and location status } \\
\text { Module 4: Appraisal Calculation }\end{array}$ \\
$\begin{array}{l}\text { 1.Selection of real estate valuation methods } \\
\text { 2.Collection and selection of comparable examples (market comparison method) } \\
\text { 3.Real estate price estimation } \\
\text { 4.Land price estimation }\end{array}$ \\
\hline \multirow{3}{*}{ Module 5: Writing Appraisal Report } & $\begin{array}{l}\text { 1.Issue the initial appraisal reply } \\
\text { 2.Issue formal appraisal report } \\
\text { 3.File the report and appraisal manuscript }\end{array}$ \\
\hline
\end{tabular}

\section{E. Diversity of the Curriculum Assessment System}

After the change of teaching mode, the curriculum assessment system should also make corresponding changes. The teaching mode should be changed from single classroom teaching to "online + offline" teaching mode. Therefore, the curriculum assessment system should also be composed of online assessment and offline assessment, which can be divided into four modules altogether:

The first module is the online course score, which is composed of online course learning and online exercises, in which online course completion accounts for $20 \%$ and exercise score for $10 \%$ (the review of online exercises can be automatically completed by the system). This module mainly assesses the mastery of students' basic theoretical knowledge.

The second module is the grades of classroom learning, which is composed of student attendance and classroom performance, of which attendance accounts for $15 \%$ and classroom performance accounts for $10 \%$.

The third module is a practice module. Through the project teaching, the teacher asks the students grouped spontaneously, with 5-6 members in each group, and issues a real estate appraisal report with the group as the unit. The teacher gives each student the corresponding score through the practical participation and evaluation report of student. This assessment module can fully reflect the comprehensive application ability and professional quality of students, so this module has a higher proportion of scores, accounting for $30 \%$ of the total score.

The fourth module is a final examination, which assesses students' mastery of basic concepts, principles and various valuation methods in the form of traditional examination papers. This part of the score accounted for $15 \%$.

\section{CONCLUSION}

The deep integration of the Internet and various industries has stimulated technological updates and organizational changes in the industry and improved the efficiency of the industry. In order to improve the comprehensiveness and effectiveness of education, it is imperative to integrate education with the Internet. "Internet + " will change the traditional model of education, effectively integrate resources, make education break through the time and space constraints, improve learning flexibility of students, but also improve the teaching quality of teachers. At the same time, the "Internet +
Education" teaching model also puts forward higher requirements for teachers. Teachers need to constantly update their professional knowledge, grasp the frontiers dynamics of the discipline, improve information literacy, master information technology skills, optimize teaching design, update teaching methods, and constantly self-improvement to meet the teaching needs of the information age.

\section{REFERENCES}

[1] Xiao Hongqiu. Thinking and Exploration of the "Online and Offline" Teaching Mode [J]. Vocational and Technical, 2016 (07): 53-54.

[2] Bai Xinhua, Wang Haitao, Li Tao. Exploration on the Teaching Reform of the Course of Real Estate Appraisal in Colleges and Universities- Based on the Cultivation of Real Estate Appraisers[J].Industrial Forum (Residential and Real Estate), 2017(08):14-15.

[3] Luo Yingshi. "Internet +" and Education [J]. Western Quality Education, 2016 (08): 8-9.

[4] Wang Wei, Hao Lianke. Research on Teaching Elements in "Internet + Education"[J]. Journal of Tonghua Teachers College (Natural Science Edition), 2018(02): 99-104.

[5] Zhu Lifang. Research on the Practice Teaching Reform of the Course of Real Estate Appraisal[J]. Education Modernization, 2016(32): 26-27.

[6] Liu Li. Research on the Design of Higher Vocational Education Valuation Based on Work Process[J]. Industrial Technology and Vocational Education, 2015, 13(01): 25-27.

[7] Wang Ziqiong. Research on Teaching Reform of Real Estate Appraisal under the View of "Internet $+"[\mathrm{~J}]$. Education and Teaching Forum, 2016(41): 69-70.

[8] Wang Dun. Project-based teaching reform of "Real Estate Appraisal" course based on working process [J].New Curriculum Research, 2017 (06): 78-80. 